\title{
De schat van Wonoboyo in de Nieuwe Kerk
}

De tentoonstelling: Indonesië: de ontdekking van het verleden laat een keuze zien van zowel antropologische als oudheidkundige Indonesische collecties die in de $19^{c}$ en eerste helft van de $20^{c}$ eeuw opgesplitst werden tussen beide genoemde musea. Er waren verschillende redenen voor zo'n opsplitsing, bijvoorbeeld: om de kosten te delen, of omdat de verzamelaar verhuisde van Indonesië naar Nederland of omgekeerd.

Drie oudheidkundige vondsten die een eeuw en nog langer geleden werden ontdekt, en die verdeeld werden tussen de musea in Jakarta en Leiden, die van Combre (1904), Muteran (1881) en Puger Wetan (1874), worden nu op de tentoonstelling weer samengevoegd. ${ }^{\prime}$ Daarnaast wordt een vifftiental gouden voonwerpen uit een recente vondst, de schat van Wonoboyo getoond. Bij het ontdekken van deze schat in 1990 was er geen sprake meer van opsplitsing. De schat van Wonoboyo is dus in zijn geheel opgenomen in het Nationaal Museum in Jakarta. Omdat deze schat de grootste en meest spectaculaire vondst is die ooit op Java werd gedaan, wordt er hier extra aandacht aan besteed.

De Wonoboyo-schat wordt genoemd naar het dorp waar hij is gevonden. $\mathrm{Hij}$ lag bedolven onder een laag lava, onder een veld in het gehucht Plosokuning, administratief vallend onder het dorp Wonoboyo (onderdistrict Jogonalan, Kebupaten Klaten), circa 20 kilometer van de Middenjavaanse stad Yogyakarta en circa 5 kilometer ten noordoosten van het bekende tempelcomplex candi Prambanan. Om een gunstiger bevloeiing van het rijstveld te verkrijgen liet de eigenaresse de grond afgraven en zo werd de schat gevonden. Dit gebeurde vrij recent, in 1990.

Deze vondst was zeer omvangrijk en was geborgen in een bronzen doos en in vijf Chinese potten van steengoed (martavanen) uit de Tang-periode (618907) van circa $35 \mathrm{~cm}$. hoog, terwijl er ook nog voorwerpen los naast lagen. ${ }^{2}$ Elk van de vinders had recht op een bepaald deel van de gevonden voorwerpen en deze delen werden stuk voor stuk ingeleverd, waarbij het onzeker blijft of dat nu alles is.

De Wonoboyo-schat bevat bijna 7000 gouden en zilveren munten, maar geen godenbeeldjes of ceremoniële gebruiksvoonwerpen, zoals wierookbranders, lampen, handbellen, offerbladen en dergelijke die meestal van brons gemaakt zijn. De gevonden voonwerpen zijn uitsluitend van goud en zilver en er zijn meerdere exemplaren aanwezig van verschillende typen lichaamssieraden, een grote variëteit aan schalen, waterscheppen, handvatten, sierstukken en 
onderdelen van wapens, aan watervaten, lotusbloemen in verschillende formaten. Onder de gouden voorwerpen bevinden zich veel voorwerpen die eerder onbekend waren. Het vakmanschap van de Wonoboyo-voorwerpen is spectaculair hoog.

\section{Overeenkomst met de vondst van Muteran}

Een aantal voorwerpen komt overeen met die in de vondst die in 1881 in het dorp Muteran werd gedaan en die in zijn oorspronkelijke samenstelling op de tentoonstelling in de Nieuwe Kerk te zien is. Het zijn met name een paar zeldzame gouden hoofddeksels en lotusbloembladen als zitkleden, en verder diademen, haarspelden, halskettingen, gordels, bovenarmbanden, etcetera. Dit zijn waarschijnlijk (resten van) twee sieradensets. Over het gebruik hiervan werden eerder verschillende mogelijkheden voorgesteld. ${ }^{3}$ Er bleef onzekerheid bestaan of de sieraden bedoeld waren tijdens plechtige ceremonieën voor een vorstelijk mensenpaar of voor beelden van een godenpaar.

Argumenten voor gebruik door een vorstenpaar zijn het niet-bestaan in het oude Java van beelden in paren van god en godin van menselijke afmeting. Ook de aanwezigheid in Vietnam van zorgvuldig bewaarde schatten met gouden en zilveren sieraden en ceremoniële voorwerpen van vorsten uit het verleden, die weliswaar van jongere datum zijn, maar wellicht juist daardoor van de bijbchorende kostbare kleding voorzien zijn, ${ }^{4}$ wijst op een gebruik door een vorstelijk echtpaar. Maar het bestaan eveneens in Vietnam van een gouden hoofddeksel met enkele bijbehorende sieraden uit de tiende eeuw van een formaat dat te klein is voor een mens, maar wel geschikt is voor een godenbeeld en ook recente vondsten van gouden sieraden voor godenbeelden, ${ }^{5}$ de zilveren stolpen met gouden hoofd van de god Shiwa voor over een linga, die recentelijk in grote getale op de kunstmarkt verschenen, ${ }^{6}$ pleiten voor gebruik voor godenbeelden. Ook in India zijn sieraden voor godenbeelden bekend, ${ }^{7}$ en in Kambodja zijn complete sets sieraden voor godenbeelden gevonden. ${ }^{8}$ Dan is er ook nog de mogelijkheid dat sommige sieraden door olifanten of paarden werden gedragen. Waarschijnlijk werden de sieraden in de Wonoboyo-schat voor alledrie doeleinden gebruikt; die van Muteran, die incompleet zijn en waarbij niet zulke grote afmetingen voorkomen, misschien alleen voor vorstenparen.

\section{De datering van de Wonoboyo-schat}

Een belangrijk verschil met bijna alle andere Javaanse oudheidkundige vondsten is, dat de gehele Wonoboyo-schat aan eenzelfde periode kan worden toegeschreven. Hij werd bij een vulkanische uitbarsting onder een circa 2,75 meter dikke laag lava bedekt. Een bestaande toestand werd dus in één klap gefixeerd. Dat betekent dat de voorwerpen toen tegelijkertijd in gebruik waren en even oud zijn. Hierbij laten we voorlopig in het midden of er zich misschien ook antieke voorwerpen tussen bevonden. Gebaseerd op de overeenkomst van het schrift van inscripties op enkele kommen met het schrift van de inscriptie van Lintakan van AD 919, kan de hele schat worden toegeschreven aan een ruime periode daaromheen, van het eind van de negende tot en met het midden van de tiende eeuw. ${ }^{9}$

Deze datering kan een bredere basis worden gegeven door vergelijking van de menselijke figuren op de twee schalen met verhalende reliëfs in de Wonoboyo- 
schat, de schaal met episodes uit het Ramayana (zie hieronder) en die met een ongeïdentificeerd verhaal ${ }^{10}$ met andere Oudjavaanse figuren. De figuren op de schalen in de Wonoboyo-schat hebben dezelfde haardracht, zijn net zo slank en bewegen zich net zo soepel als de twee spuierbeelden in de vorm van een man met een kalebas onder de arm, en een vrouw met een kalebas in de handen, die aangetroffen werden bij het Oostjavaanse dorp Mojokerto. ${ }^{11}$ De vindplaats bij Mojokerto zou, net als bij de Muteran-vondst, kunnen wijzen op een ontstaansperiode in de eerste helft van de tiende eeuw. ${ }^{12}$ Dezelfde slankheid en beweeglijkheid kenmerkt de prinselijke personages op de spuierreliëfs van de heilige badplaats Jolotundo die ook het haar op dezelfde manier opgemaakt hebben. ${ }^{13}$ Bovendien heeft de Garuda die de zwangere prinses Mrigawati ontvoert op het Jolotunda-reliëf,, ${ }^{14}$ veel weg van de toverluchtwagen waarop Sita door Rawana wordt weggevoerd op de Ramayanaschaal (paneel 3, scène 2). De badplaats Jolotundo is gedateerd door een inscriptie met het omgerekende jaartal AD 977. ${ }^{15}$ De combinatie van het schrift van circa 919 en het jaartal 977 van Jolotundo, geeft een toeschrijving van de twee schalen, en dus van de gehele Wonoboyo-schat, aan de tiende eeuw en vóór het jaar 977. Nog drie andere Javaanse voorwerpen, namelijk twee bekroningen van onbekende voorwerpen, de één een man te paard, de ander een hoofs liefdespaar uit onze eigen collectie (zie afbeelding) ${ }^{16}$ en een bronzen beeldje van Shri Devi, ${ }^{17}$ kunnen vanwege hun overeenkomstige haardracht en fysionomie aan dezelfde periode worden toegeschreven.

\section{Hindoeïstisch of boeddhistisch?}

Alleen bij uitzondering geven Javaanse oudheden uitsluitsel of ze tot een bepaalde religie behoren. In de Wonoboyo-schat bevinden zich een aantal voorwerpen die op een Wishnoe-verering kunnen wijzen: de Ramayanaschaal, de amulethouder (hieronder afb. 7 en 5) en het paar ringen met schelphoorn en rad. ${ }^{18}$ Dat is bijzonder, omdat in het hindoeïsme op Java, Shiwa steeds veruit het belangrijkst is. In hofliteratuur daarentegen, speelt één van Wishnoe's incarnaties, Krishna, wel een belangrijke rol.

Er is geen herkenbaar boeddhistisch voonwerp bij, tenzij eventueel het paar hoofddeksels. Als de Wonoboyo-schat inderdaad in één keer onder de lava gefixeerd is en dus aan één heiligdom, of één wereldse instelling toebehoorde, kan men er van uit gaan dat de boedel tot één godsdienst behoorde. In dit geval zou dus het paar hoofddeksels hindoeïstisch moeten zijn. Dat impliceert dat de spiralen waarmee ze bedekt zijn, geen haarkrullen van de boeddha kunnen voorstellen. De draairichting lijkt er niet toe te doen: bij de grootste van Wonoboyo draaien ze naar links, bij alle drie andere, de kleine van Wonoboyo en de twee uit de Muteran-vondst, naar rechts. De spiralen zien er dan ook anders uit dan haarkrullen van de boeddha. Die zijn korter, lijken meer op een slakkenhuis, en draaien altijd naar rechts. Mochten de hoofddeksels toch boeddhistisch zijn, dan hoeft de Ramayana-schaal er geen contrast mee te vormen. Het Ramayana wordt vaker, bijvoorbeeld in Thailand, in een boeddhistische context opgenomen.

\section{Religieus of werelds?}

Vanwege de aanwezigheid van wereldse zaken is de Wonoboyo-schat wel geinterpreteerd als de inhoud van de kluis van de familie van de Rakryan van Halu, een hoge functionaris. ${ }^{19}$ 


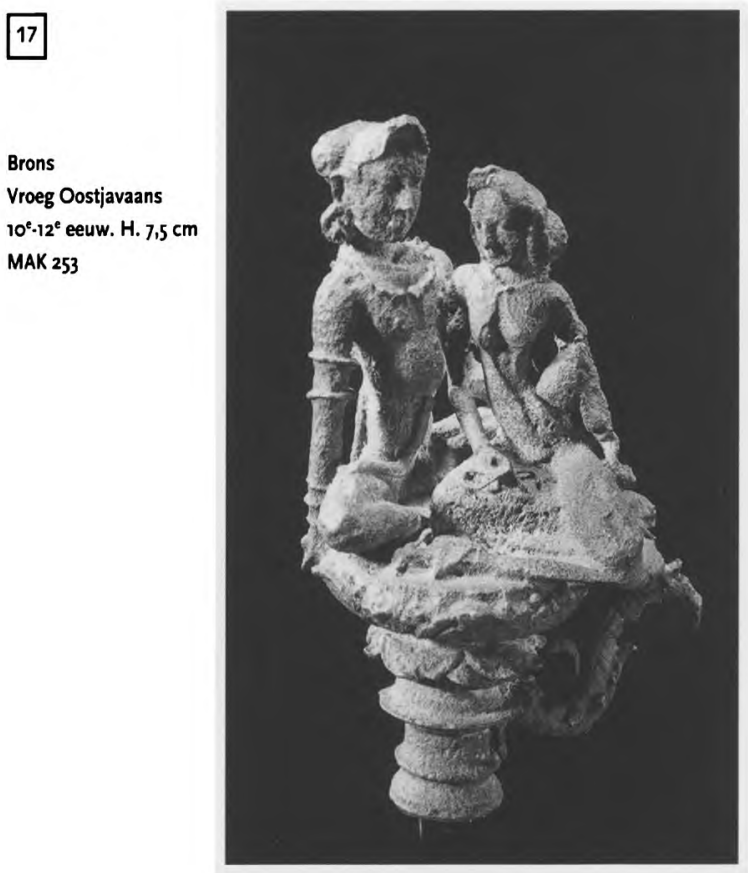

Bij sieraden denkt men misschien in de eerste plaats aan ijdelheid en wereldse zaken, maar de meeste sieraden in de Wonoboyo-schat lijken niet werelds te zijn. Vorstelijke personages in de tiende eeuw droegen dit soort sieraden niet, is nu bekend van de figuren op de Ramayana-schaal en de andere daarmee vergeleken voorwerpen. Het is de outillage van goden. Als bijzondere mensen zoals een vorstelijk echtpaar, ze bij speciale gelegenheden droegen, dan werden ze geïdentificeerd met goden.

Veel van de sieraden, zoals de bovenarmbanden, de majestueuze halsketting en het buikband-uit-een-stuk, ${ }^{20}$ zijn erg groot voor een Javaans mens. Waren ze misschien bedoeld voor de goden zelf, in de vorm van godenbeelden die ermee aangekleed werden? Ook is de mogelijkheid geopperd dat sommige door statieolifanten of -paarden gedragen werden. Welke van deze mogelijkheden het ook geweest is, ${ }^{21}$ het lijkt er op dat het religieuze aspect steeds de boventoon voert.

\section{Vorm en versiering van de voorwerpen}

Zowel opvallend veel siermotieven, als vormen in de Wonoboyo-schat zijn imitaties in goud van bestaande voorwerpen en onderwerpen uit de natuur. Daarnaast is er bij de schalen invloed van Chinees vaatwerk. De siermotieven die aan de natuur ontleend zijn hebben waarschijnlijk een bepaalde betekenis, want siermotieven als pure decoratie is niet waarschijnlijk in een cultuur als die van het oude Java. Bovenstaande opmerkingen gelden voor de Wonoboyo-schat in zijn geheel, maar de voorwerpen zelf zijn zo bijzonder dat ze apart besproken worden. 


\section{Afbeelding 1}

Twee sieraden voor over de haarknot boven op het hoofd.

Kleinere: h. $11,2 \mathrm{~cm}$., diam. 10,6 cm., NMI, inv. 8922

Grotere: h. 13,5 cm., diam. 11,2 cm., NMI, inv. 8923

Deze twee hoofddeksels, waarschijnlijk stolpen over de haarknot boven op het hoofd, vormen een ongelijk paar. De grootste is bedekt met zeven rijen spiralen die naar links draaien, de kleinere met vijf rijen die naar rechts draaien. De top van elk bestaat uit een transparante kristallen bal op een lotus. De bal wordt met twee kruislings geplaatste bandjes op zijn plaats gehouden. Aan de binnenkant bevindt zich een bronzen voering ter versteviging. ${ }^{22}$

Een vergelijkbaar ongelijk paar hoofddeksels, maar met kristallen ballen gevat in de sikkels van wajra, bevindt zich in de Muteran-vondst (afb. la en lb). ${ }^{23}$ Die van Muteran zijn door de bekroning van een wajra onmiskenbaar boeddhistisch; die van Wonoboyo ondanks de haarkrulachtige spiralen, waarschijnlijk hindoeïstisch (zie boven). De hoofddeksels zouden gediend kunnen hebben als ceremoniële sieraden van een vorst en vorstin ${ }^{24}$ maar er zijn ook andere mogelijkheden (zie boven en noot 1).
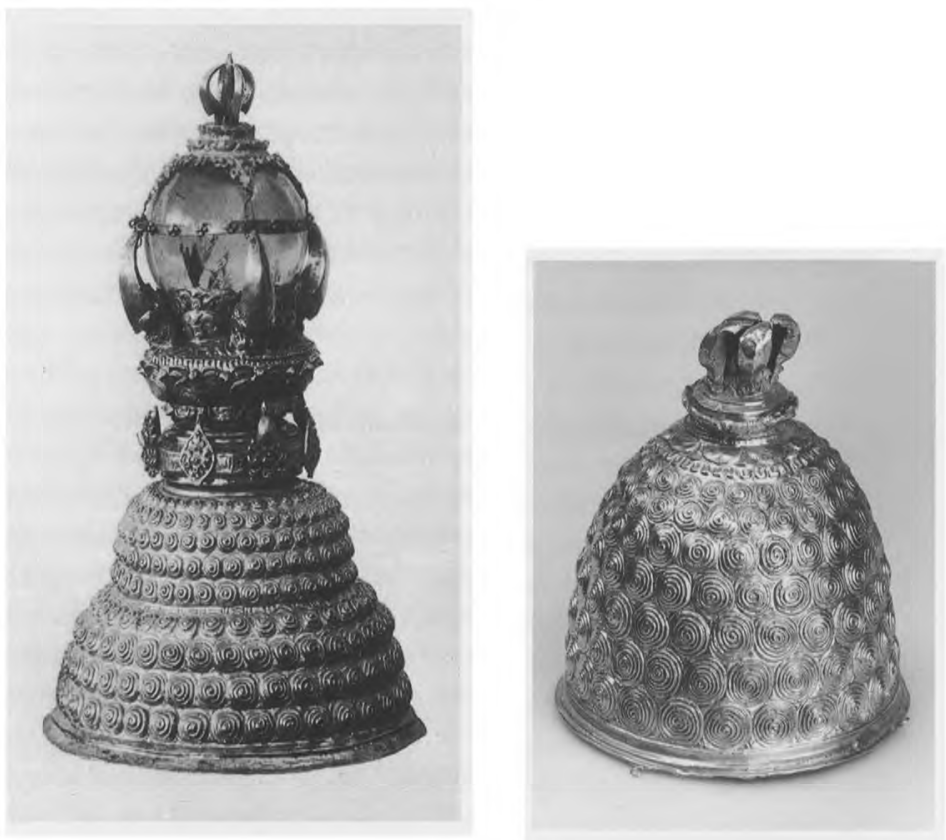
19

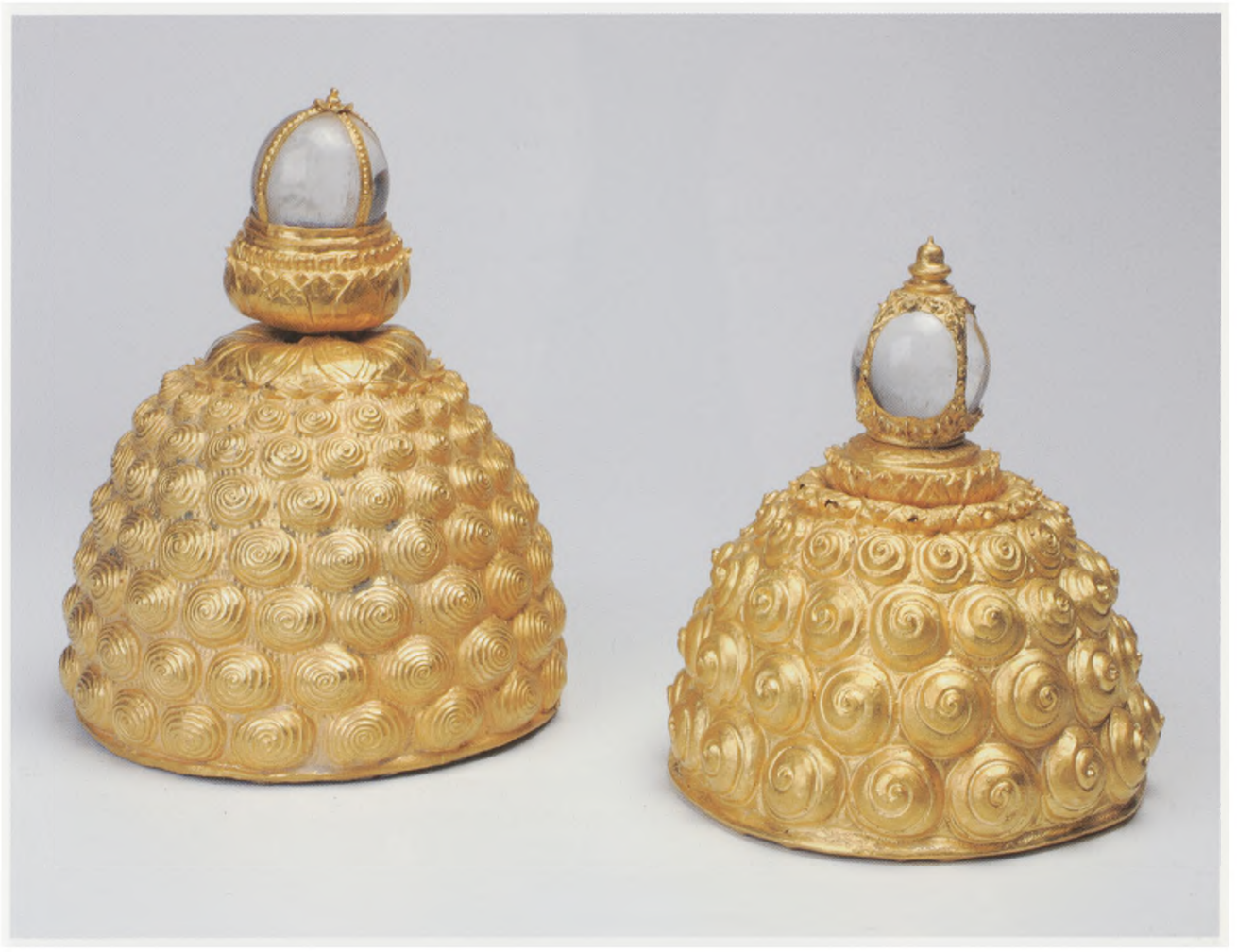



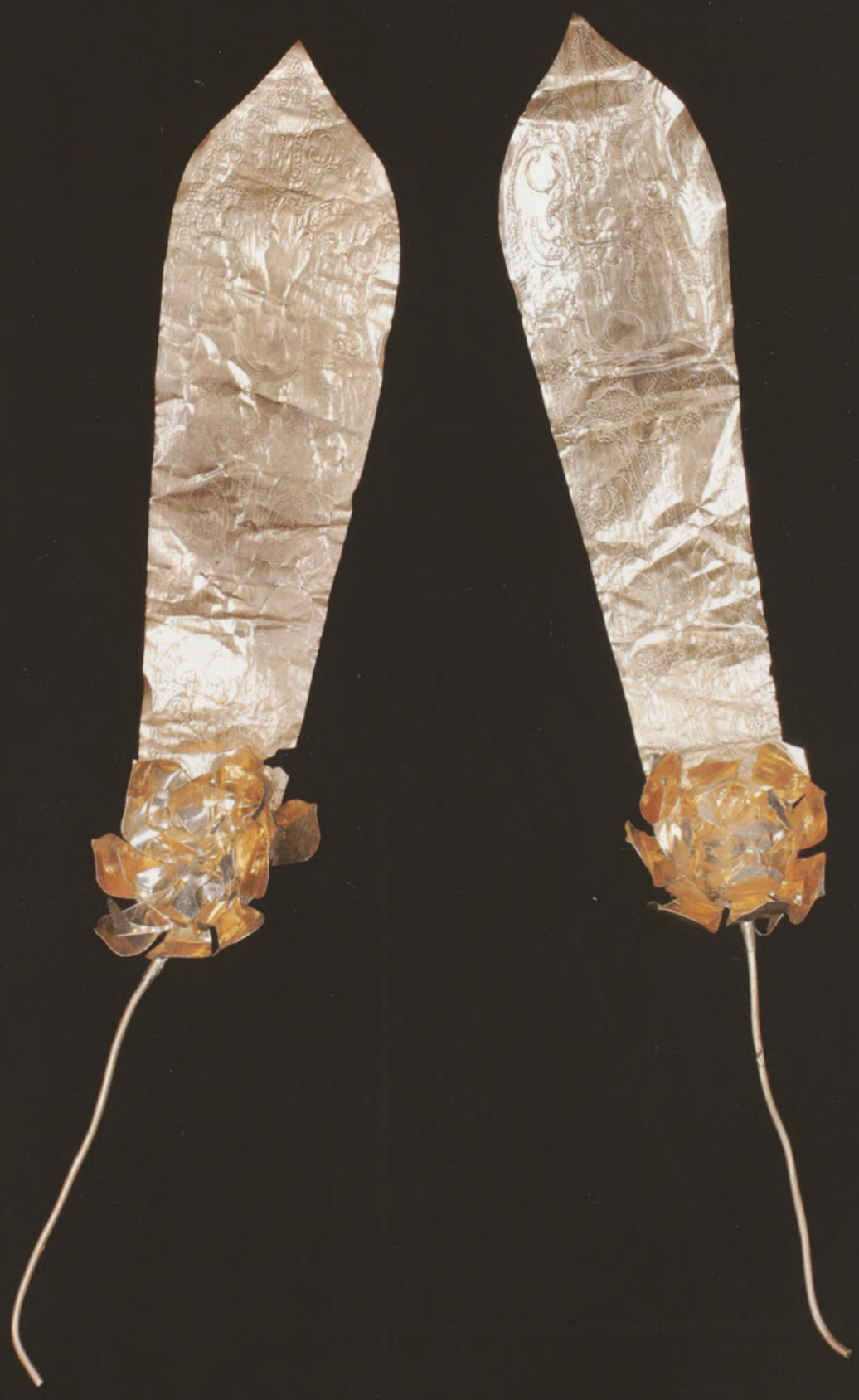


\section{Afbeelding 2}

Een paar sieraden voor boven-achter het oor.

L. 12,5 cm., NMI, inv. $8912 \mathrm{a}-\mathrm{b}$

Dit oorsieraad bestaat uit een langwerpig blad van bladgoud en een lotusbloem van drie lagen bladgoud die tegen de onderkant van het blad bevestigd is. Het sieraad werd hoogstwaarschijnlijk direct boven het oor gedragen, zodat het blad schuin omhoog stak en de bloem de bovenrand van het oor bedekte en tegen de slaap rustte. De metalen draad aan de achterkant werd over de bovenrand van de oorschelp gebogen om hem op zijn plaats te houden. Een dergelijk sieraad wordt op deze manier gedragen door het grote, negende-eeuwse, bronzen beeld van Shiwa uit Tegal ( $\mathrm{afb} .2 \mathrm{a}) .{ }^{25} \mathrm{Er}$ is een tweede paar van dit type oorsieraden in de Wonoboyo-schat. ${ }^{26}$

Een veel latere variant waar blad en bloem tot een geheel zijn gemaakt, wordt bewaard in het Museum Nusantara in Delft. ${ }^{27}$ Dat oorsieraad is van verguld zilver en de bloem is met edelstenen bezet. Het paar dateert waarschijnlijk uit het eind van de $19^{\circ}$ eeuw, toen dit soort sieraden door de sultan van Yogjakarta werd gedragen, zoals blijkt uit een statiefoto van Sultan Hamengkubuwono VII (1877-1921) uit ongeveer $1880 .{ }^{28}$ Dit sieraad, dat nog door Sultan Hamengkubuwono X bij zijn inauguratie op 7 maart 1989 werd gedragen ${ }^{29}$ en tot op de dag van vandaag door bruidegoms op Java wordt gedragen, gaat dus terug tot de negende eeuw.

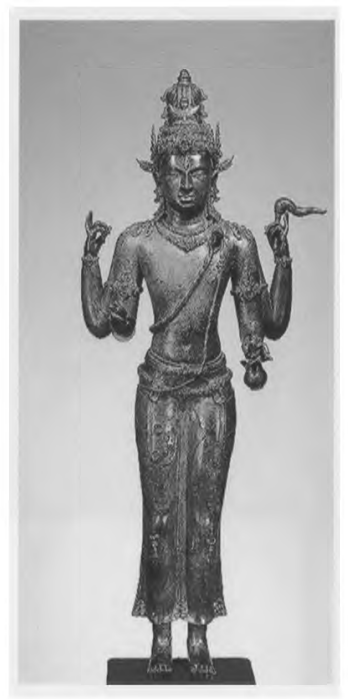




\section{Afbeelding 3}

Halsketting van imitatie koro-pedang-bonen

L. 5,5 - 2,5 cm., b. 2,5 - 1,4 cm., NMI, inv. 8874

Deze majestueuze halsketting bestaat uit twee maal vijftien gelijkvormige elementen waarvan het formaat van groot naar klein gaat. Van het ene vijftiental buigt de punt naar rechts; van het andere naar links. Alleen het allergrootste en centrale element bestaat uit spiegelbeeldige helften waarvan de punt naar beneden loopt. Zoals te zien is aan een ander sieraad uit de Wonoboyo-schat (afb. 4) werden ze van groot naar klein geregen, de grootste aan weerszijde van het centrale element.

De elementen zijn glad aan de achterkant, zijn hol, en stellen waarschijnlijk de gestileerde boon van de koro pedang (sword bean / canavalia ensiformia (L) D.C.) voor ${ }^{30}$ en geen tijgerklauwen. ${ }^{31}$

Van dit type elementen zijn er veel overgebleven, allemaal een beetje anders. Sommige zijn plat, andere bol, sommige hebben een rond kokertje om ze mee aan een koord te rijgen, anderen, zoals deze, een rechthoekig kokertje (afb.

3a). ${ }^{32}$ Zulke halskettingen worden gedragen door Brahma op een stenen beeld ${ }^{33}$ en door de Shiwaïtische leraar Agastya op een zilveren beeldje. ${ }^{34}$ Door wie ze in werkelijkheid werden gedragen, blijft onzeker.

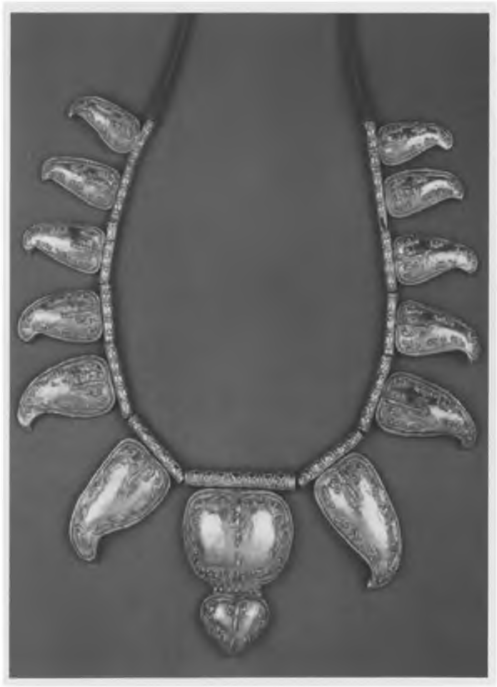




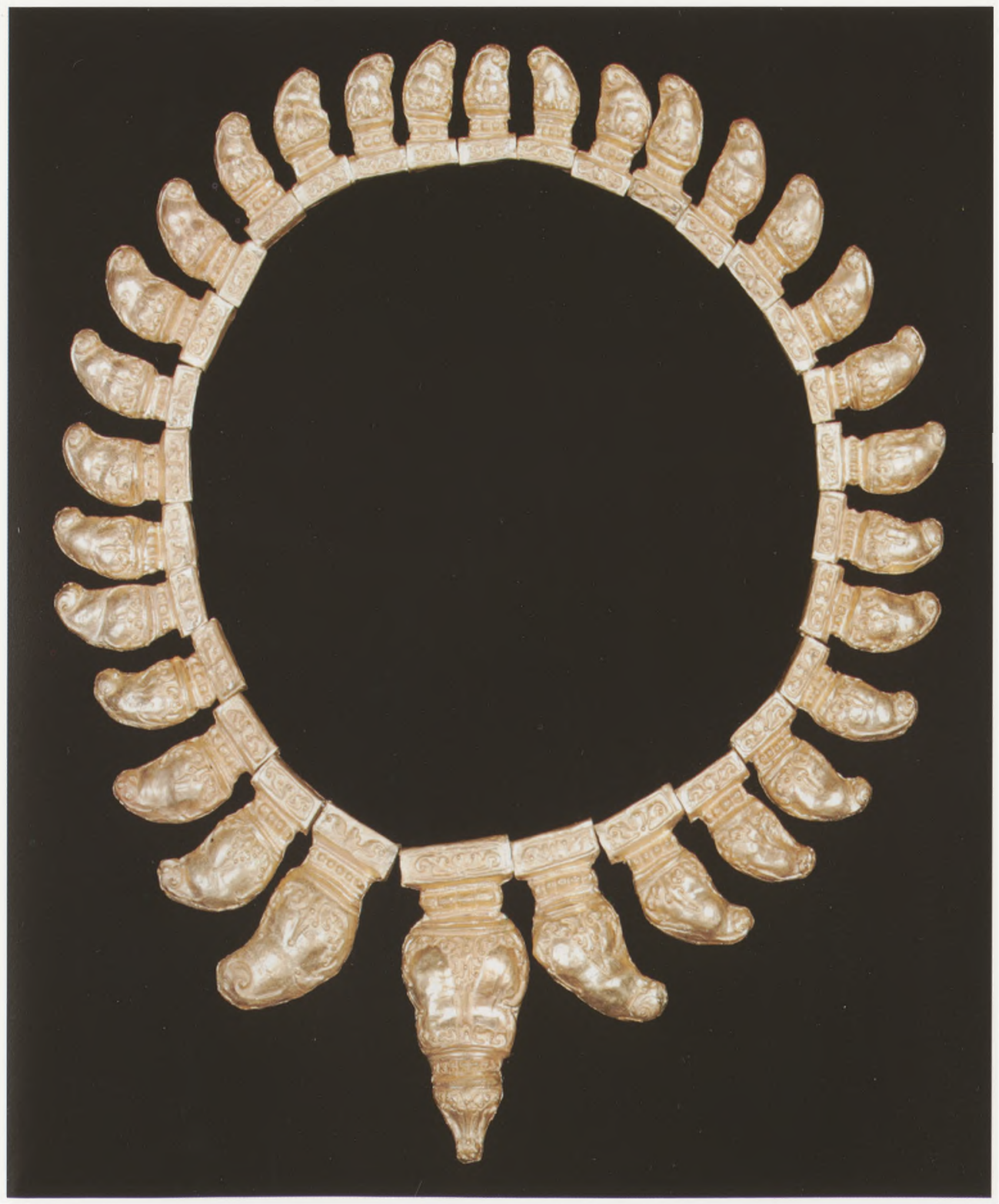




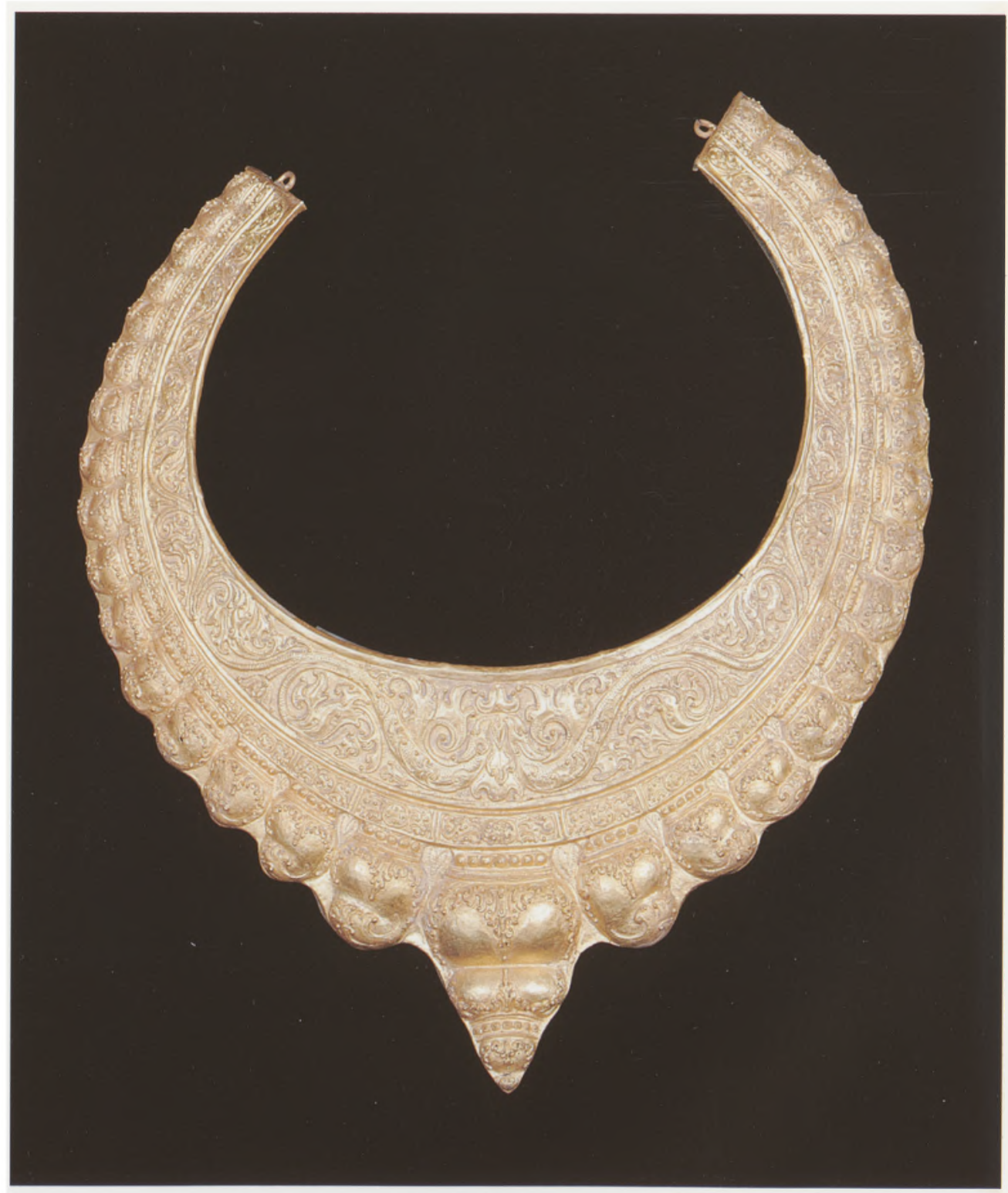




\section{Afbeelding 4}

Hals- of borstsieraad samengesteld uit twee soorten sieraden.

B. $37.4 \mathrm{~cm}$., NMI, inv. 9001

Dit sieraad is een samenvoeging van twee andere soorten halssieraden die in de Wonoboyo-schat voorkomen: een halssieraad in de vorm van een maansikkel uit één stuk ${ }^{35}$ en de halsketting van koro pedang-bonen (afb. 3). De laatste is om de eerste heen aangebracht. Door de oogjes aan de uiteinden werd een koord gehaald om het sieraad mee vast te strikken.

Elk deel van het sieraad heeft een eigen versiering. Het binnenste deel van twee vissen waarvan de staarten uitlopen in sierlijk golvende ranken naar de uiteinden van het sieraad toe. De koploze voorkanten van de vissen zijn naar elkaar toe gewend en raken elkaar in het midden juist niet. In plaats daarvan buigen de vissenlijven iets naar boven en glijden als het ware over een grote mensenneus heen. Daarboven draaien twee ranken naar weerskanten en vormen zo een paar spiraal-ogen. Het effect van dit lijnenspel is een afschrikwekkende monsterkop. Een zelfde versiering, maar dan zonder mensenneus, maar met een groot juweel op een lotuskussen tussen de ogen, is toegepast op een van de paren bovenarmbanden uit de Wonoboyo-schat. ${ }^{36}$ Het buitenste sieraad heeft kortere en bredere elementen met een stompere punt dan de ketting met losse elementen in de Wonoboyo-schat (afb. 3). De rijgkokertjes zijn rechthoekig.

Door het formaat zou dit sieraad alleen geschikt zijn voor een mens van uitzonderlijk robuuste lichaamsbouw; het lijkt niet waarschijnlijk dat die in het oude Java te vinden was. Was het dan bedoeld voor een dier, een statiepaard of -olifant, zoals wel in processies in verhalende reliëfs op de Borobudur wordt afgebeeld, ${ }^{37}$ of misschien voor godenbeelden? Het tot één sieraad samenvoegen van de ketting van koro pedang-bonen en de maansikkelvormige bewijst in ieder geval dat beide typen door eenzelfde wezen gedragen werden. 
Afbeelding 5

Amulethouder.

H. $9,2 \mathrm{~cm}$. b. $10 \mathrm{~cm}$. d. $2,3 \mathrm{~cm}$. , NMI, inv. 8916

Dit doosje is aan alle zijden in repoussé-techniek versierd, maar de versiering op de twee grote vlakken is het belangrijkst. Midden onder is daar een lotusbloem weergegeven, waaruit drie stelen omhoog krullen met elk weer een lotusbloem. Elke bloem draagt op het hart een attribuut van de hindoegod Wishnoe. Het middelste is het grootst en het belangrijkst. Op de ene kant staat de schelphoorn met het zwaard en de knots aan weerszijde; op de andere kant van het doosje het rad met de boog en pijl. ${ }^{38}$ De attributen, behalve de schelphoorn, hebben een vlam in top, het rad ook nog vlammen opzij.

Er is mij geen tweede exemplaar van een dergelijk doosje uit de Oudjavaanse periode bekend. Het koord dat er voor zorgt dat de deksel open en dicht kan zonder weg te raken, zal tegelijkertijd als draagkoord gediend hebben.

Waarschijnlijk was het bedoeld, zoals ook Wahyono al suggereerde, om het met magische teksten of kleine voorwerpen te vullen die de drager beschermen tegen kwaad. ${ }^{39}$ Dit is zonder twijfel een zeldzaam Wishnuitisch voorwerp. 


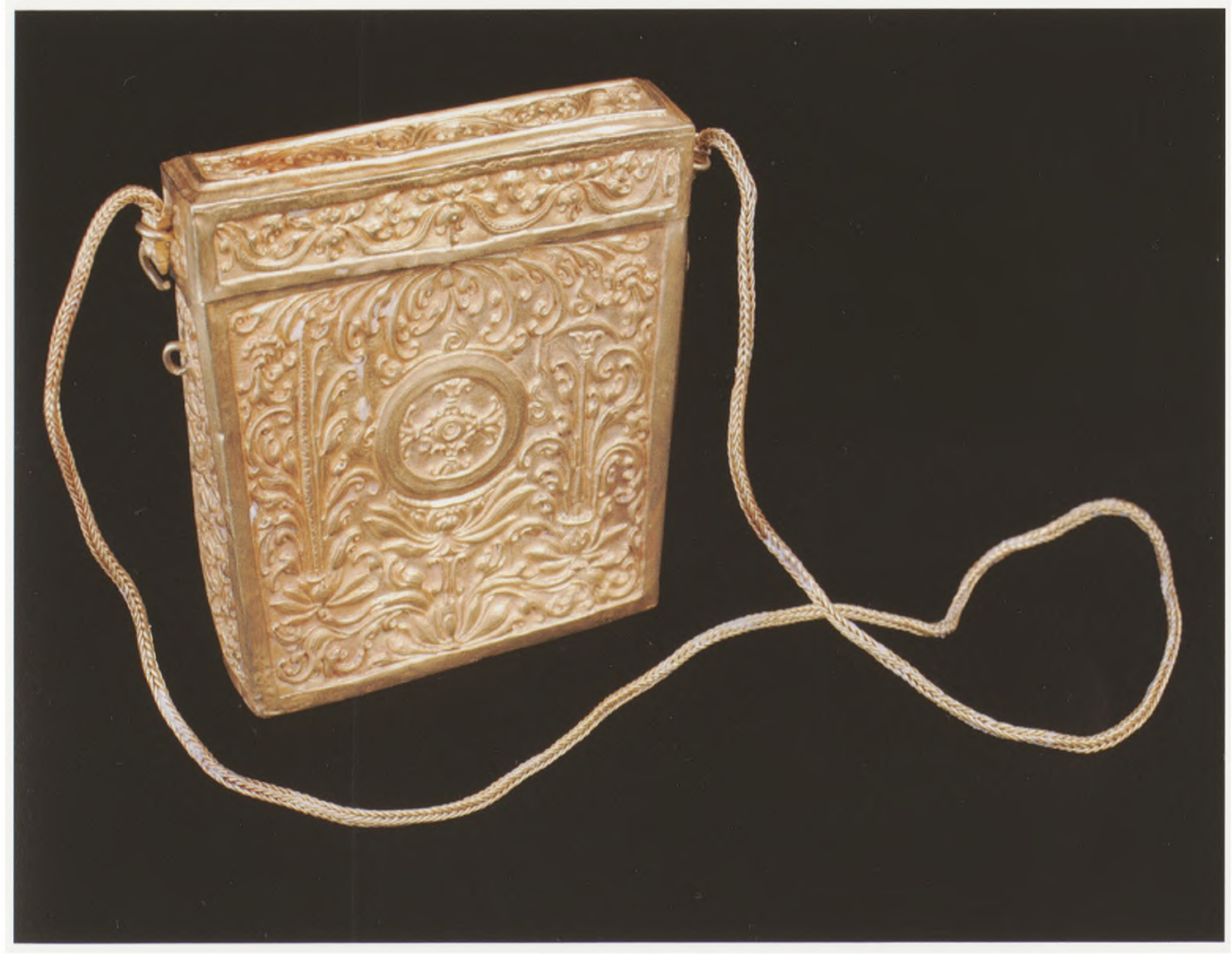




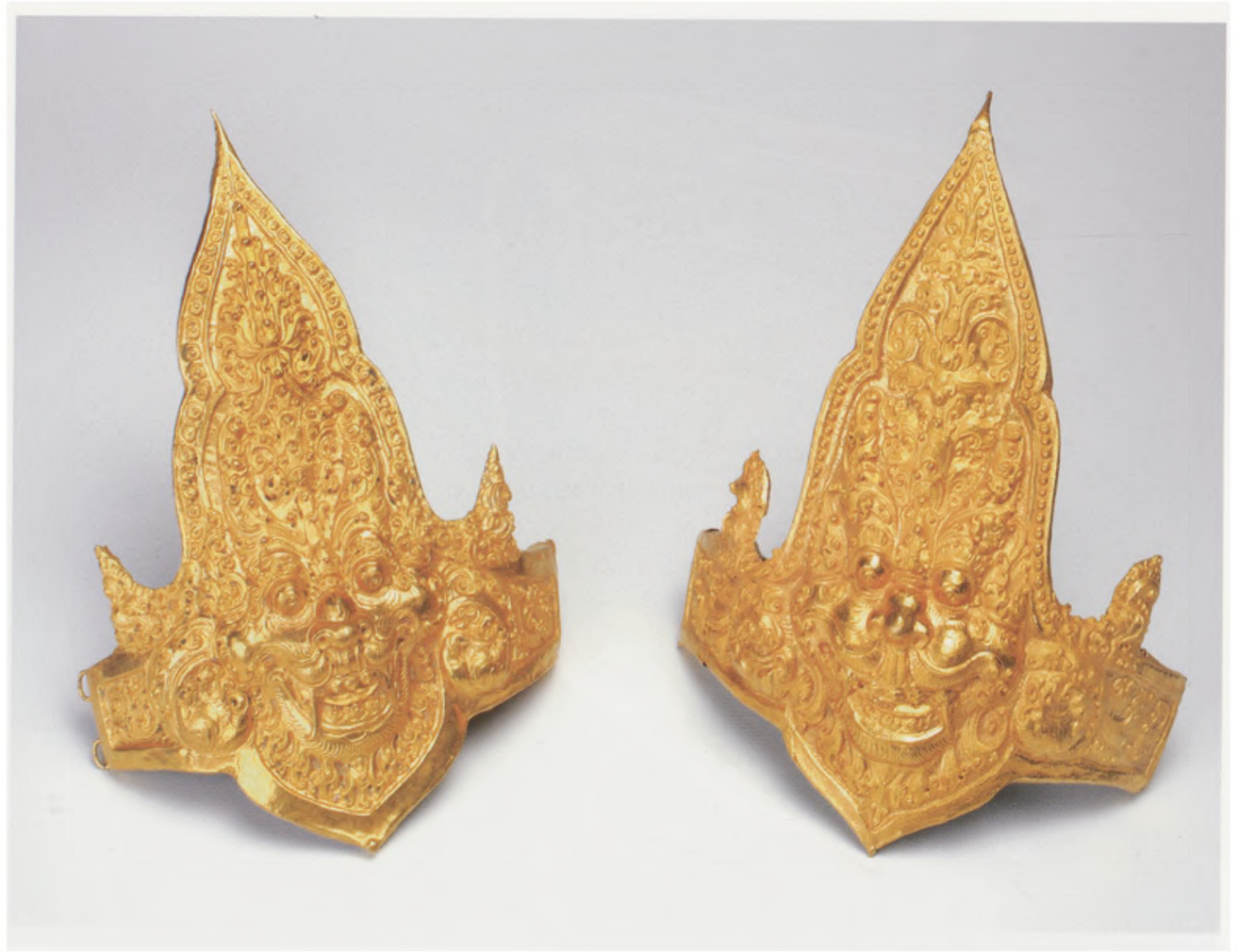




\section{Afbeelding 6}

Een paar bovenarmbanden versierd met cen afschrikwekkende monsterkop.

H. 19,5 cm., b. 14,4 cm, NMI, inv. 9006

Deze forse bovenarmbanden zijn versierd met een prominente kala-kop. Kala-koppen behoren tot de hemelse sferen en zijn het bekendst van hun aanwezigheid midden boven ingangen van tempels en nissen met godenbeelden. Ze dienen tot afweer van kwade invloeden en worden dan gecombineerd met een makara aan weerszijden van de onderkant. Hier zijn de makara's ook aanwezig, maar klein en ter hoogte van de kala-neus.

De kala-kop hier houdt het midden tussen een Midden- en een Oostjavaanse kala. Hoewel er niet een rechtlijnige ontwikkeling bestaat van kala-koppen van de Midden- naar de Oostjavaanse periode, zijn er wel enkele belangrijke verschillen tussen die twee. De meeste Middenjavaanse kala's hebben geen onderkaak en geen klauwen aan weerszijden en één of meer bloemen onder de bovenkaak. De kala-kop van de Oostjavaanse candi Jago uit de $14^{e}$ eeuw (afb. 6a) heeft mensenhanden met grote scherpe nagels. ${ }^{40}$

Hij steekt wijs- en middelvinger dreigend omhoog. Die kop is verder nog voorzien van hoorns, slangen en een doodskop. De kala-kop hier is zonder die toevoegingen al afschrikwekkend genoeg, met de opengetrokken muil die lange slagtanden en brede kiezen bloot legt, de opgeheven tijgerpoten die scherpe klauwen tonen en de grote, bolle spiraalogen die blinde woede lijken uit te drukken.

Aan de beide uiteinden van de bovenarmband zijn twee ooges bevestigd waar een koord doorheen gehaald kan worden om het om de bovenarm te strikken. Deze lichaamssieraden zijn erg fors voor een Javaans mens. ${ }^{41}$ Bovenarmbanden met kala-kop, maar dan in de typische Middenjavaanse variëteit zonder onderkaak of poten aan weerszijde, worden gedragen door het centrale Shiwa-beeld van candi Prambanan uit het midden van de negende eeuw. ${ }^{42}$ Zouden die van Wonoboyo dan ook voor een godenbeeld bedoeld geweest zijn?

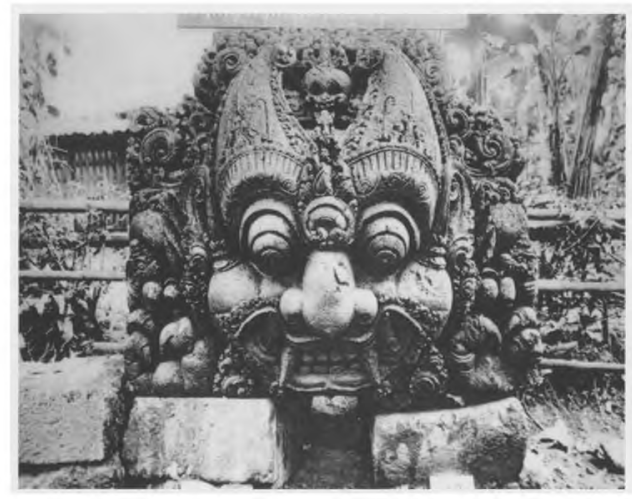


Schaal versierd met acht episoden uit het Ramayana, o.a. de roof van Sita.

L. $28,8 \mathrm{~cm}$., b. $14,4 \mathrm{~cm}$, h. $9,3 \mathrm{~cm}$., NMI, inv. 8965

Het allerspectaculairste stuk uit de Wonoboyo-schat is zonder twijfel deze Ramayana-schaal. De vorm die ovaal en vierlobbig is, op een eveneens ovale en vierlobbige voet, komt zelden voor in het oude Java. Mij is alleen nog een gladde, bronzen schaal zonder voet bekend..$^{43}$ Deze vorm is ontleend aan Chinese schalen uit de Tang-periode ( $\mathrm{afb}$. 7a en b).

De Ramayana-schaal is over het hele oppervlak uitbundig versierd in repoussé. Deze techniek werd in het oude Java veel en met grote vaardigheid toegepast en in deze Ramayana-schaal met onovertroffen meesterschap. De voet is versierd met een rand van wat wel 'mammiform' motieven genoemd worden. ${ }^{44}$ Langs de hele bovenrand van de Ramayana-schaal loopt een band van driehoekige, afhangende bladeren die doen denken aan de bladerrand langs de dakranden van paviljoens en baldakijnen boven zetels waarin zich vorsten of stoepa's bevinden, in vele verhalende reliëfs van de Borobudur.

De rondlopende wanden van de schaal zijn bewerkt met voorstellingen. De vier panelen van de lobben zijn van elkaar gescheiden door een verticale streep. Elk paneel bevat twee scènes van een verhaal. Er is geen begin of eind aangegeven, maar het is wel duidelijk dat de scènes van rechts naar links lopen. Er bestaat geen twijfel dat het om het bekende Ramayana-heldendicht gaat, evenmin dat het de episode betreft van de roof van Sita door de demonenvorst Rawana. Wanneer prins Rama met zijn vrouw Sita en zijn broer Laksmana tijdens zijn verbanning in het oerwoud verblijt, gaat hij er op uit om een gouden hert voor Sita te vangen. Van zijn afwezigheid maakt Rawana in vermomming van bedelmonnik gebruik om Sita te benaderen en op zijn toverluchtwagen te ontvoeren naar zijn eilandrijk Langka. Daar houdt hij haar omringd door dienaressen gevangen met de bedoeling haar goedschiks of kwaadschiks tot zijn echtgenote te maken. Over de interpretatie van enkele scènes bestaat echter verschil van mening en ook welke scène de eerste en de laatste is. ${ }^{45}$

Paneel 1 , scène 1: als eerste scène: Rama groet zijn vader ten afscheid voor zijn vertrek in ballingschap. Of: Laksmana begroet Rama nederig. Of als laatste scène: Rama treurt met Laksmana om het verlies van Sita.

Paneel 1, scène 2: Prins Rama en zijn echtgenote Sita leven in ballingschap in het woud. Ze zitten op een bank; Rama's broer Laksmana zit voor hun op de grond. Sita ziet een gouden hert passeren.

Paneel 2, scène 1: Rama gaat met pijl en boog achter het gouden hert aan om het voor Sita te vangen.

Paneel 2, scène 2: Wanneer Rama het gouden hert met zijn pijl dodelijk treft, ontpopt het zich als de demon Marici, een dienaar van Rawana.

Paneel 3, scène 1: Intussen sleurt een prinselijke figuur de alleen achtergebleven en tegenspartelende Sita mee. De enige overblijfselen van zijn vermomming als bedelmonnik, de rinkelstaf en bedelnap die nu hun taak vervuld hebben, liggen afgedaan op de grond.

Paneel 3, scène 2: De prinselijke figuur vertoont zich als de demonenkoning Rawana met tien hoofden wanneer hij Sita over zijn knieën liggend meevoert in zijn toverluchtwagen.

Paneel 4, scène 1: Rama geneest de Shabara-vrouw van haar lelijke uiterlijk. 


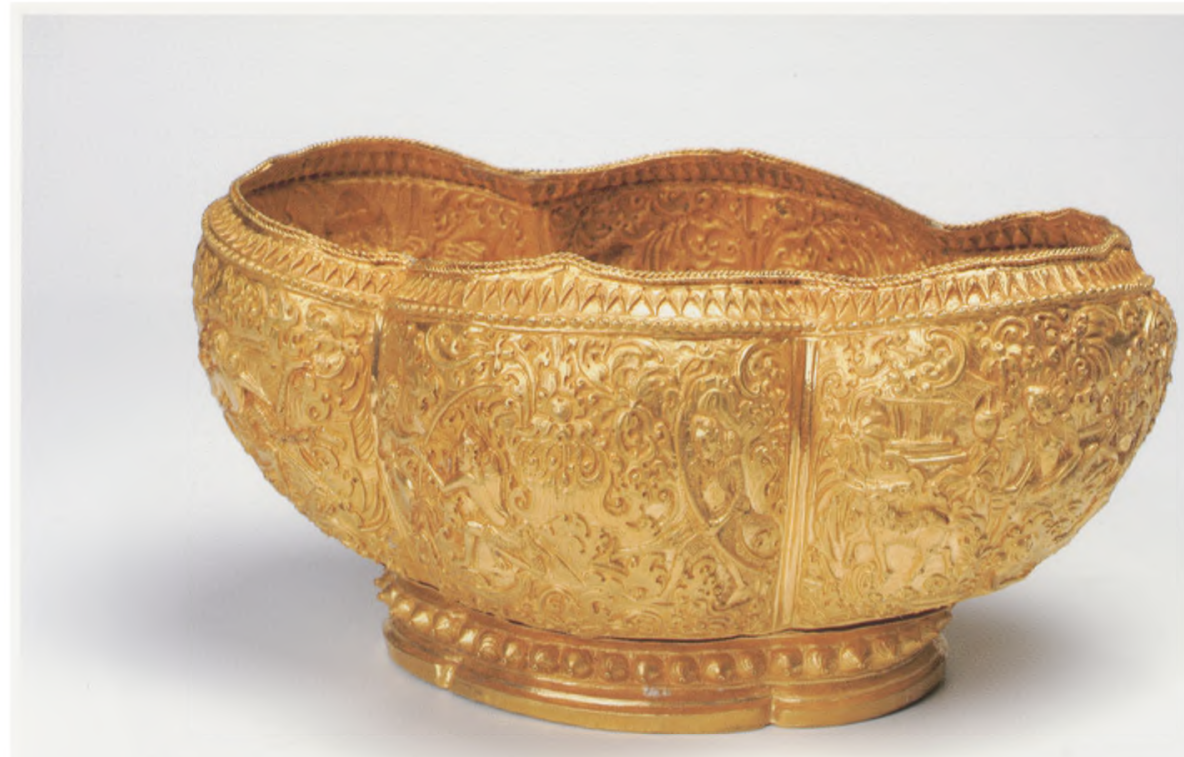

Of: Trijata de dienares, door Rawana aan Sita toegewezen, verzoekt Rawana dringend Sita's liefde niet af te dwingen. Of: Rawana probeert Sita voor zich te winnen.

Paneel 4, scène 2: Sita treurt afgewend liggend op een rustbed, terwijl twee dienaressen van Rawana meelevend toekijken. Of: Twee door Rawana aangewezen dienaressen luisteren naar de klagende Sita.

De scènes spelen zich af tegen een achtergrond van fantasierijke vegetatie waartussen wellicht een bestaande boom of plant, zoals de kokospalm, te ontdekken valt. ${ }^{46}$

De karakters van het heldendicht zijn in hun uiterlijk aangepast aan de mode van de tijd waarin de schaal gemaakt is. Bovendien is Rawana als prins en niet als demon voorgesteld, en alleen reizend in zijn luchtwagen vertoont hij zich in zijn veelkoppige gestalte. Hij is dus van dezelfde stand als Rama, maar vijandig. Het is daarom mogelijk dat ook de keuze van de episodes verband houdt met gebeurtenissen uit de tijd. ${ }^{47}$
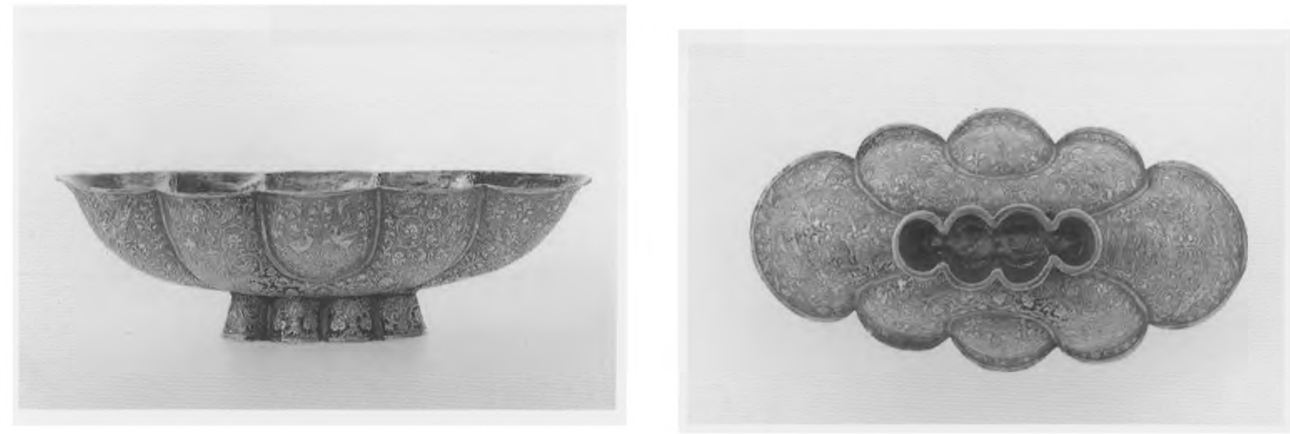
(3) 


\section{Afbeelding 8}

Wateremmer van imitatie palmblad.

L. $15,6 \mathrm{~cm}$., b. 5,7 cm., h. 6,6 cm. , NMI, inv. 8997

Deze schaal is een imitatie van een eenvoudig gebruiksvoorwerp, een wateremmer gemaakt van gedroogde bladeren van de lontar- of palmyrapalm. Een dwarsbalkje dat de twee randen van de lange kanten verbindt en iets naast het midden is geplaatst, dient tot handvat en maakt het draaien van het vat bij het waterscheppen gemakkelijker. ${ }^{48}$ Het edelmetaal waarvan deze schaal gemaakt is, wijst op alles behalve een alledaags gebruik. Het toepassen van palmbladeren voor allerlei vlechtwerk voor huishoudelijke voorwerpen zoals een wateremmer met schep, was bekend uit de $19^{e}$ en $20^{e}$ eeuw (afb. 8a), ${ }^{49}$ maar is hiermee ook vastgelegd voor de tiende eeuw.

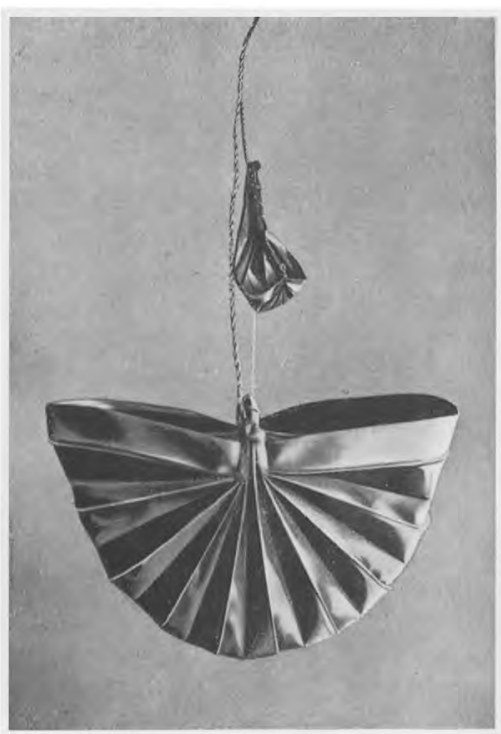


Rijk versierde deksel van een pot van steengoed.

H. $7 \mathrm{~cm}$., diam. 12,2 cm, NMI, inv. 8933

Deze deksel behoort bij een type pot dat zich ook in de Wonoboyo-schat bevindt. ${ }^{50}$ Dergelijke potten van brons, met onversierde deksel en van een groter formaat hebben in werkelijkheid bestaan (afb. 9a). ${ }^{51}$ Potten van hetzelfde type komen ook voor als attribuut van godheden, zoals bijvoorbeeld Agastya, en als vaas-van-overvloed op tempelmuren. ${ }^{52}$

De opzet van de versiering van deze deksel is gelijk aan die van de andere gouden deksels: een knop, een twee maal vier driehoekige versiering over de bolling en hier een reeks dezelfde 'mammiform' motiefjes om de rand. Nog twee van dergelijke deksels bevinden zich in de Wonoboyo-schat, alle met een oogje voor een kettinkje waarmee de deksel met de oorspronkelijke pot verbonden was, net als bij de pot met deksel hier. ${ }^{53}$

Een vierde gouden deksel met gelijksoortige versiering is samen met een uitbundig versierde gouden tuit gevonden. Die tuit heeft de vorm van een vyala, een steigerende leeuw met een kuif op de kop en de hals bedekt met krullende manen. De opengesperde bek doet dienst als tuit. ${ }^{54}$ In de Wonoboyo-schat bevindt zich een gouden tuit van een dergelijk gecompliceerde vorm..$^{55}$ Deze wordt gevormd door een makara waarvan de bovenlip niet zoals gewoonlijk in een elegant gekrulde olifantsslurf uitloopt, maar in een leeuwenkop met opengesperde bek. Deze bek is de tuit. In de openstaande muil van de makara bevindt zich een kinnari, een fantasiewezen met het lichaam van een vogel en het hoofd en de borsten van een mensenvrouw. Makara met een leeuw als bovenlip komen voor aan candi Bubrah, de zuidelijke voortempel van candi Sewu uit het einde van de achtste eeuw..$^{56}$ In de vroege Oostjavaanse periode vormen makara de spuiers die het water van de bergen in de bassins van heilige badplaatsen voeren.

De gouden deksels en tuiten waren waarschijnlijk oorspronkelijk bevestigd op potten van steengoed of brons, zoals bijvoorbeeld afgebeeld op een verhalend reliëf van candi Prambanan uit het midden van de negende eeuw. ${ }^{57}$ Het kostbare materiaal en de uitbundige versiering wijzen weer op een ceremoniële functie.

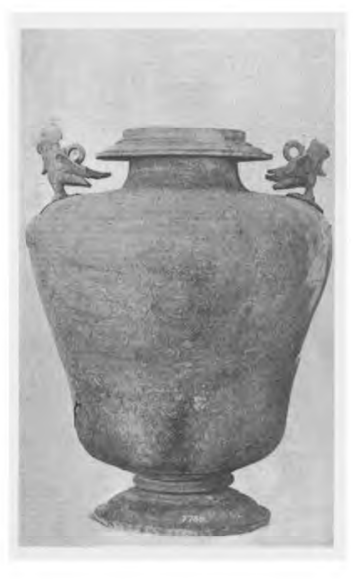




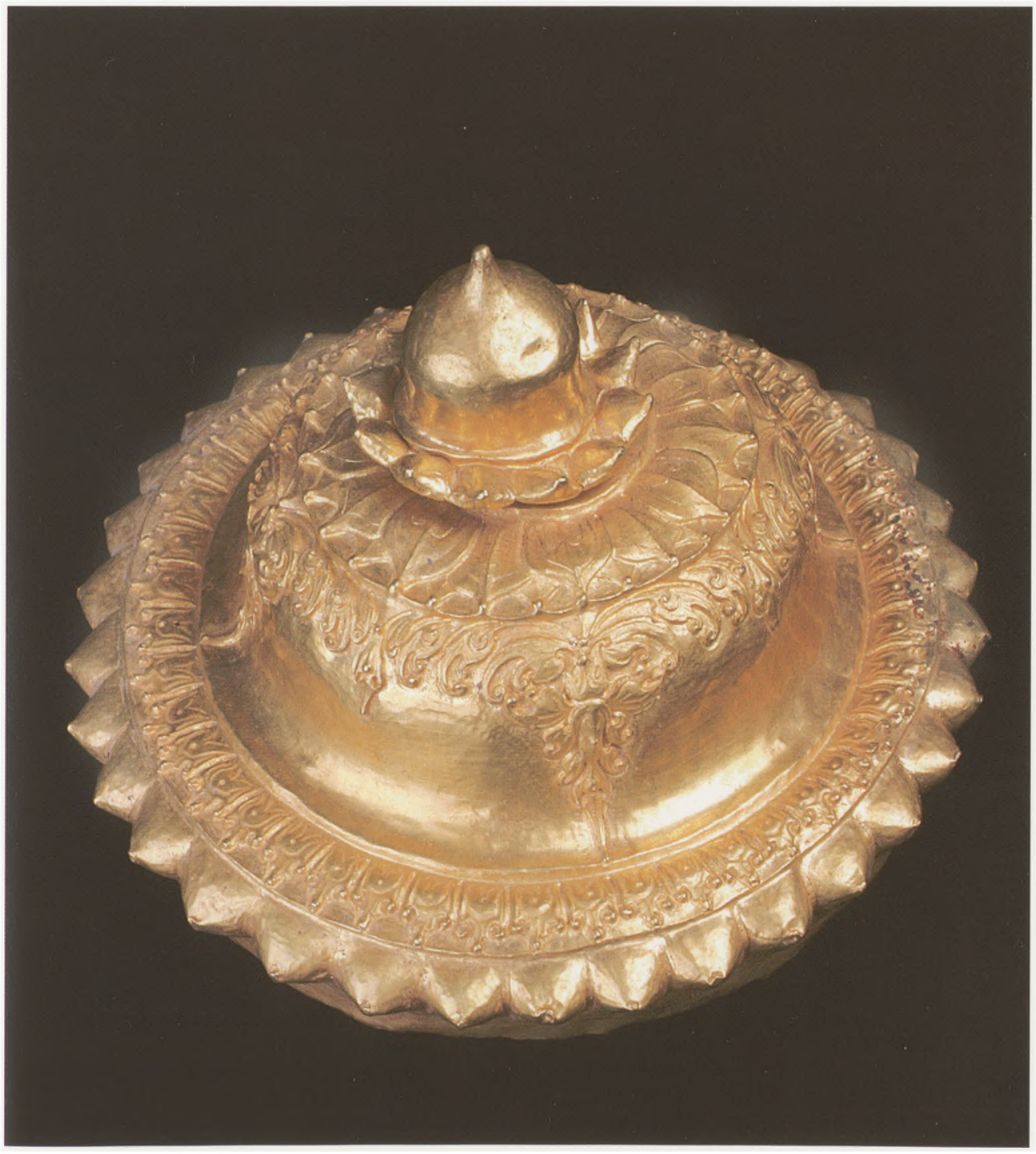




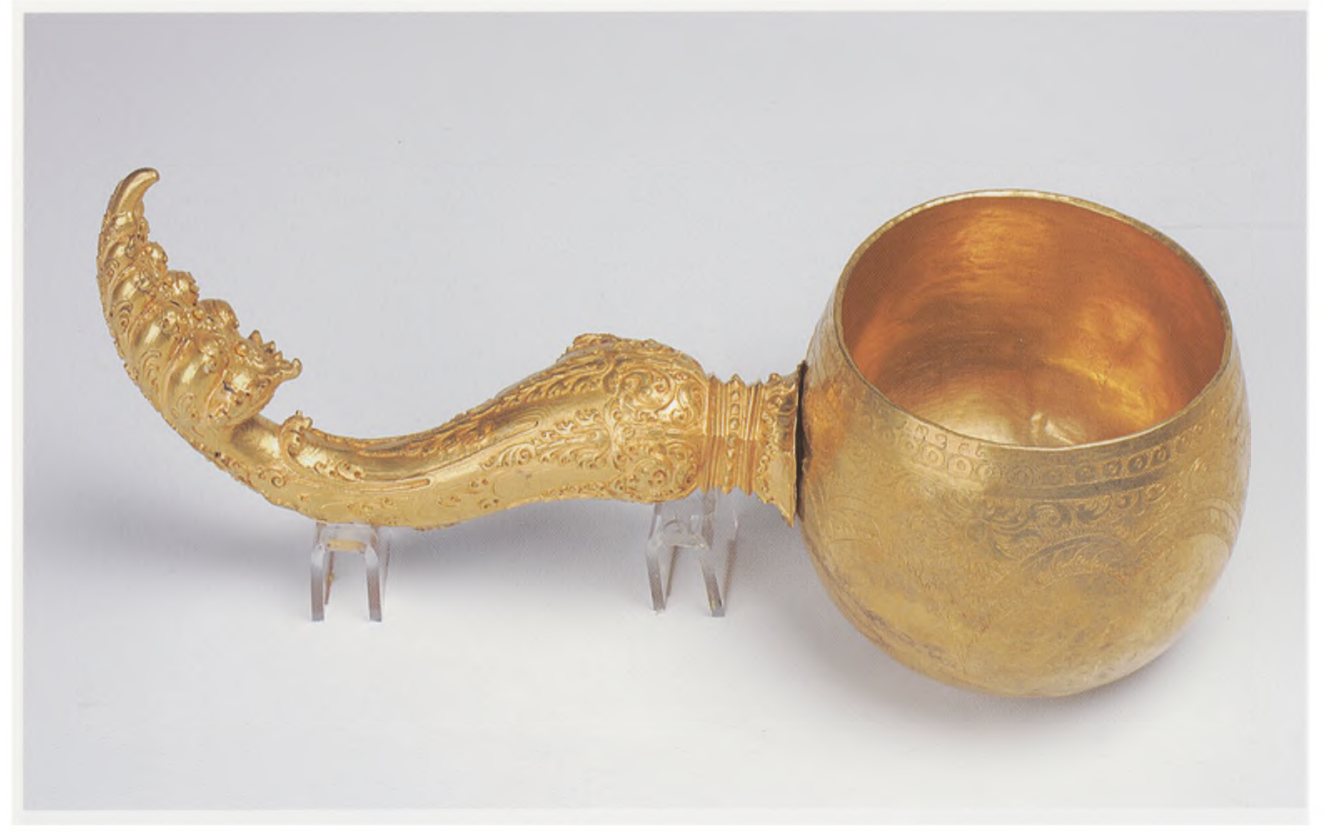




\section{Afbeelding 10}

Waterschep van imitatie klapperdop met een ontluikende varen als handvat.

H. $3,2 \mathrm{~cm}$., diam. 10,3 cm., NMI, inv. 8990

Deze gouden waterschep is een imitatie van een waterschep in vergankelijk materiaal. Het voorbeeld was een afgezaagde kokosnoot met de steel van een ontluikend blad van een varen. ${ }^{58}$ Een dergelijke waterschep hangend aan een watervat, is afgebeeld op Ramayana-reliëfs op candi Prambanan uit het midden van de negende eeuw..$^{59}$

De versiering die om de opening is aangebracht, bestaat weer uit vier grote driehoekige motieven afgewisseld met kleinere driehoeken, opgevuld met hele fijne stippeling die wel het 'viskuit-motief' wordt genoemd. Daarin zijn weer bloemmotieven, met aan weerszijde een rank, uitgespaard. Deze bloemmotieven komen ook voor op twee voorwerpen uit de Muteran-vondst. ${ }^{60}$ In de Wonoboyo-schat bevindt zich een tweede gouden waterschep van dezelfde vorm, maar daar wordt de steel gevormd door een ontluikend blad van een andere plant, misschien ook een varen. ${ }^{6 !}$ 


\section{Afbeelding 11}

Handgreep misschien van een instrument om palmbad geschrikt te maken om op te schrijven

L. $20 \mathrm{~cm}$., diam. 2,6 cm., NMI, inv. 8967

Deze compacte koker met een lichte kromming aan een uiteinde, is in de lengte versierd met opengewerkte banen van golvende ranken. Om één uiteinde is de versiering aangebracht van vier driehoeken, die veel voorkomt bij voorwerpen in de Wonoboyo-schat. Dit uiteinde vertoond roest. Dit wijst op de oorspronkelijke aanwezigheid van een mes of pen van ijzer. In het andere uiteinde is een afgeronde steen gestoken. Dit voorwerp is wel voor een zwaardgreep gehouden. ${ }^{62} \mathrm{Mij}$ komt dat onwaarschijnlijk voor. Het is daarvoor veel te lang en te krom. Bovendien ziet de echte zwaardgreep in de Wonoboyoschat er totaal anders uit. ${ }^{63}$

Waarvan de koker dan wel een handgreep is, is niet eenvoudig te bepalen. Er bestaat nog een tweede exemplaar in het Museum Sono Budoyo in Yogyakarta, alleen is dat van brons. Het heeft ook een gepolijste steen aan een uiteinde. Hoe mooi ook, deze steen is geen versiering, maar een werktuig. Is de handgreep misschien een instrument om een bepaald materiaal geschikt te maken om erop te schrijven?

Het is lang niet duidelijk met welke instrumenten de dichters aan de hoven in de Oudjavaanse periode schreven. Waarop geschreven werd, moet zoiets geweest zijn als een schrijfplankje, dat groot genoeg moet zijn om in noodgeval boven het hoofd te houden en tot paraplu te dienen. Uit hofliteratuur blijkt dat het zo in voorkomende gevallen wordt toegepast. Het moet van een ander, steviger materiaal geweest zijn dan palmblad, dus bijvoorbeeld hout, bamboe of boombast. ${ }^{6+}$ Welk materiaal het dan ook was, het zal altijd nodig geweest zijn om het te prepareren, namelijk om het met een mes in vorm te snijden, het oppervlak te impregneren en vervolgens te polijsten door er met een gladde steen over te wrijven. De steen aan het ene uiteinde van de Wonoboyo-handgreep is bij uitstek geschikt voor het polijsten, en in het andere uiteinde zou het benodigde mes hebben kunnen steken.

Alle kleurenfoto's zijn gemaakt door Ben Grishaaver, Leiden. 
39

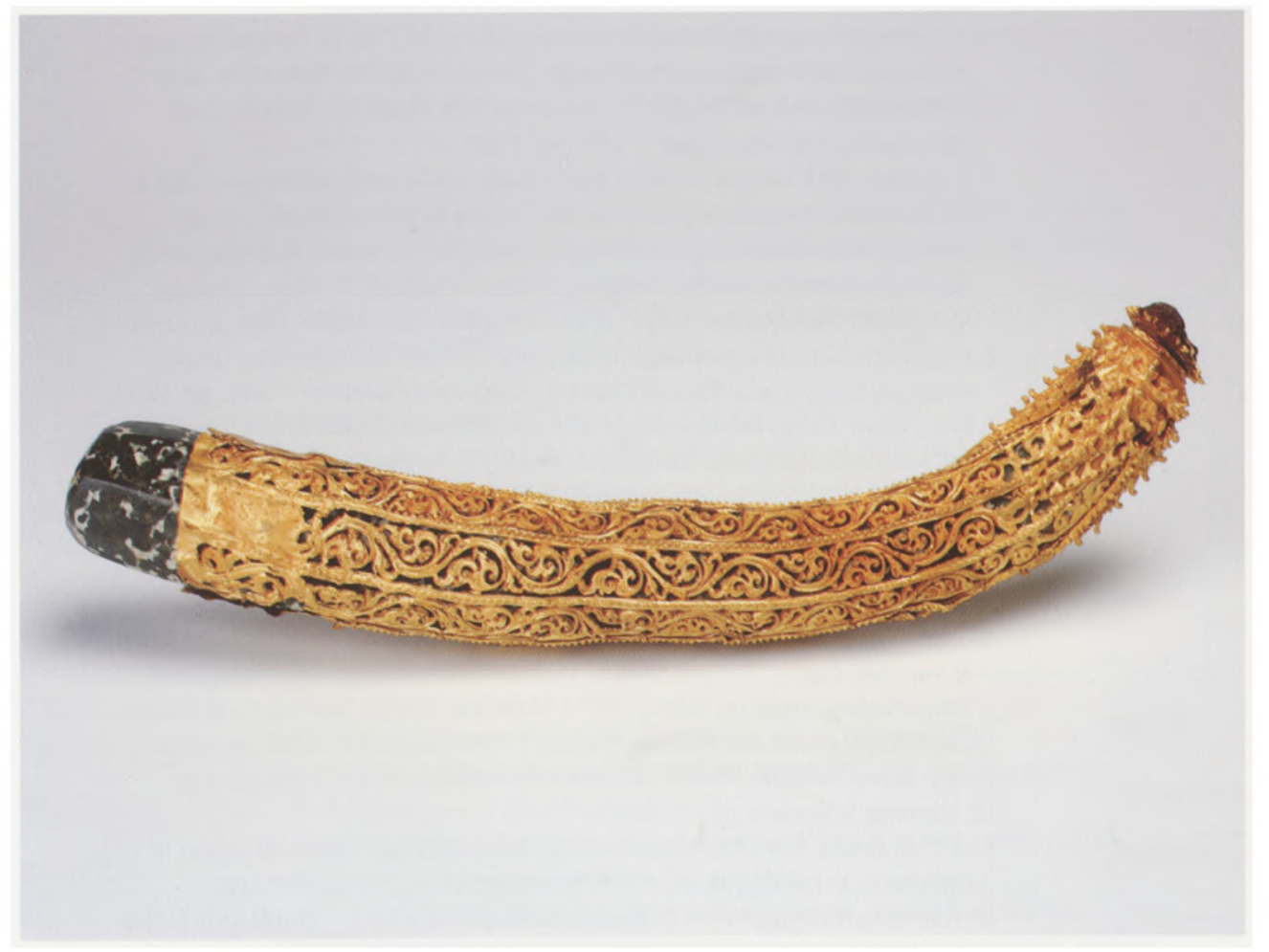


1. Voor de vondsten van Puger Wetan, Muteran en Combre, zie de tentoonstellingscatalogus. Voor Javaanse oudheidkundige vondsten in het algemeen, zie P. Lunsingh Scheurleer, 'Oudheidkundige vondsten op Java', in deze aflevering.

2. Wahyono Martowikrido, 'The Gold of Wonoboyo. Preliminary notes' in: W.H. Kal (red.) Old Javanese Gold (4th-15th century). An archaeometrical approach. (Bulletin Royal Tropical Institute 334), KIT, Amsterdam, 1994, pp. 30-45

3. P. Lunsingh Scheurleer, 'De vondst van Muteran in 1881 ', in Sri Hardiati Endang en P. ter Keurs (red.), Indonesia: de Ontdekking van het Verleden, Amsterdam, 2005

4. H. Parmentier en E.-M. Durand, 'Le Trésor des Rois Chams', Bulletin de l'École français d'Extrême orient, tome V, 1905, pp. 1-46

5. A. Richter, The Jewelry of Southeast Asia, London, 2000, nr. 53: Is het toeval dat de kokerarmband een rand van spiralen heeft, net als de gouden stolpen over de haarknot in de vondsten van Wonoboyo en Muteran? En zou de holle lotusbloem bovenop het hoofddeksel niet een glazen bol bevat hebben? T. White, 'Precious Metalwork from Ancient Champa', Arts of Asia (32/4), July-August 2004, pp. 62-71.

6. P. Baptiste, 'Un étui couvre-linga au musée des Arts asiatiques-Guimet. Un rare témoin de l'orfèvrerie de l'ancien Champa', Revue du Louvre, fasc. 3, 2002, pp. 13-17.

7. M.L. Nigam, Indian Jewellery, New Delhi, pp. 63-66; Ch. Nanda Gopal, 'Jewellery in the Temples of Karnataka', in: Susan S. (red.), The Jewels of India, Bombay, 1995. pp. 37-52.

8. E.C. Bunker, 'Splendour and Sensuality in Angkor Period Khmer Jewellery', Orientations, March 2000, pp. 102-113.

9. Wahyono, op.cit, noot 2 .

10. K. Kartik, 'The Gold Treasure of Wonoboyo at the Jakarta National Museum', Arts of Asia, July-August 1995, pp. 96-102; Treasures of Ancient Indonesian Kingdoms, Tokyo National Museum, Tokyo, 1997; I. Mardiana, 'Ancient lavanese Gold Artefacts. Collection of the Jakarta National Museum', Arts of Asia (23/5), 2003, pp. 57-65.

11. A.J. Bernet Kempers, Ancient Indonesian Art, Amsterdam, 1959, pls. 189-190.

12. Lunsingh Scheurleer, op.cit., noot 3.

13. F.D.K. Bosch, 'The Oldjavanese bathing place Jalatunda', in Selected Studies in Indonesian Archaeology by Dr. F.D.K. Bosch, Den Haag, 1961, pp. 47-108.

14. J. Fontein, The Sculpture of Indonesia. National Gallery of Art, Washington \& New York, 1990, nr. 18.

15. Bosch, op.cit., noot 13.

16. P. Lunsingh Scheurleer, \& M.J. Klokke, Divine Bronze. Ancient Indonesian Bronzes from AD 600 to 1600. Rijksmuseum, Amsterdam \& Leiden, 1988, nrs. 110 en 111.

17. C. Levin, 'Classical Javanese gold reflects some new light on the Ramayana', in: W.H. Kal (red.), Precious Metals in Early South East Asia. Proceedings of the second seminar on Gold Studies, Royal Tropical Institute, Amsterdam, 1994, pp. 39-44, pp. 40-41.

18. Treasures, op.cit., noot 10, nr. 111.

19. J. Wisseman Christie, A Preliminary Survey of Early Javanese Coinage Held in Javanese Collections, Jakarta, 1995, p. 22.

20. Treasures, op.cit., noot 10, nr. 108.

21. Zie ook de functie van de Muteran-vondst, Lunsingh Scheurleer, op.cit., noot 3.

22. Treasures, op.cit., noot 10, nr. 90 .

23. Lunsingh Scheurleer, op.cit., noot 3.

24. Wahyono, op.cit., noot 2, pp. 35-36.

25. Treasures, op.cit., noot 10, nr. 50 .

26. Treasures, op.cit., noot 10, nr. 93.

27. Kriss \& Sarong. Masculin et Féminin dans l'archipel indonésien, Musée des Arts asiatiques, Nice. 2002, no. 69.

28. H.I. Jessup, Court Arts of Indonesia, The Asia Society, New York, 1990, p. 217.

29. Vriendelijke informatie van Stuart Robson.

30. Wahyono in: Les Ors de l'Archipel Indonésien, Musée national des Arts asiatiques- 
Guimet, Parijs, 1995, nr. 18 en in Versunkene Königreiche Indonesiens, Mainz, 1995, nr. 43.

31. P. Lunsingh Scheurleer, 'Gold Javanese Jewellery', Arts of Asia, July-Augustus, 1994, pp. 44-54.

32. Fontein, op.cit., noot 13, nr. 111 ; Jessup, op.cit., noot 27, fig. 191; W.F. Stutterheim, 'De Oudheden-Collectie van Z.H. Mangkoenagoro VII te Soerakarta', Djawa (17/1-

2), Jan.-Mei 1937, pp. 3-112, fig. 49; Lunsingh Scheurleer, op.cit., noot 3.

33. Fontein, op.cit., noot 14, nr. 111.

34. P.H. Pott, 'On a Silver Figure of Bhatara Guru from Sumatra', Ethnologische Zeitschrift Zürich, I, 1972, pp. 291-295.

35. Wahyono, op.cit., noot 30, no. 32; Treasures, op.cit., noot 10, nr. 100.

36. Les Ors, op.cit., noot 30, nr. 30.

37. Les Ors, op.cit., noot 30, nr. 32.

38. Dat het hier om een pijl gaat, en niet om een parasol, zoals elders beschreven, is een observatie van Jaap Polak, Amsterdam; vergelijk de pijl die Rama in zijn hand houdt op paneel 2, scène 1 van de Ramayana-schaal (nr. 7).

39. Wahyono in Versunkene Königreiche, op.cit., noot 30, nr. 39.

40. Bernet Kempers, op.cit., noot 11, pl. 232.

41. Wahyono, Les Ors, op.cit., noot 30, nr. 29.

42. Bernet Kempers, op.cit., noot 11, pls. 157-158.

43. J.E. Van Lohuizen, Indo-Javanese Metalwork, Linden-Museum, Stuttgart, 184, nr. 177.

44. 'mammiform', d.w.z. in de vorm van een vrouwenborst, Wahyono, Les Ors, op.cit., noot 30, nr. 21.

45. Wahyono in Les Ors, op.cit., noot 28, nr. 21; Levin, op.cit., noot 16; Willem Van der Molen, 'Rama and Sita in Wonoboyo', Bijdragen tot de Taal-, Land-en Volkenkunde dl. 159 , afl. 2-3, 2003, pp. 389-403.

46.Wahyono in Les Ors, op.cit., noot 30, p. 83.

47. Levin, op.cit., noot 17.

48. Zie ook Wahyono in Versunkene Königreiche, op.cit., noot 30, nr. 46.

49. J.A. Loebèr, 'Antiquiteiten op Java', Nederlandsch-Indië, Oud en Nieuw (6/8), december, 1921, pp. 261-274, afb. 2.

50. Treasures, op.cit., noot 10, nr. 74; Art of Southeast Asia, New York, 1998, nr. 749. Hoogte $11,1 \mathrm{~cm}$. Doorsnede $8,9 \mathrm{~cm}$., inv. nr. 8929.

51. Lunsingh Scheurleer \& Klokke, op.cit., noot 16, cat, nr. 93; Jaarboek van het Koninklijk Bataviaasch Genootschap voor Kunsten en Wetenschappen, deel X, Batavia 1948-1951, nrs. 7785-7791.

52. P. Lunsingh Scheurleer (red.), Asiatic Art in the Rijksmuseum, Amsterdam, 1985, nr. 175; Bernet Kempers, op.cit., noot 11, pls. 99-130.

53. Wahyono, op.cit., noot 2, p. 34.

54. J. Miksic, Old Javanese Gold, Singapore, 1990, p. 94; Lunsingh Scheurleer, op.cit., noot 31 .

55. Treasures, op.cit., noot 10, nr. 87.

56. Bernet Kempers, op.cit., noot 11, pl. 108.

57. A.J. Bernet Kempers, Ageless Borobudur. Buddhisl Mystery in Stone, Decay and Restauration, Mendut and Pawon, Folklore in Ancient Java, Wassenaar, 1976, pl. 177. 58. Wahyono in Les Ors, op.cit., noot 30, nr. 31.

59. W.F. Stutterheim, Rama-Legenden und Rama-reliefs in Indonesien, München, 1925 , afb. 34 en 53. Ook op Sri Lanka waren waterscheppen van deze vorm bekend, gemaakt van hout, en in luxueuze uitvoering in zilver en ivoor, zie A.K. Coomaraswamy, Mediaeval Sinhalese Art, 2e editie, Londen, 1956, pls. XIII 7-9 en XLI 3.

60. Lunsingh Scheurleer, op.cit., noot 3.

61. Versunkene Königreiche, op.cit., noot 30, nr. 34.

62. Treasures, op.cit., noot 10, nr. 116; Versunkene Königreiche, op.cit., noot 30, nr. 38.

63. Mardiana, op.cit, noot 9, nr. 20; Treasures, op.cit., noot 10, nr. 117.

64. P.J. Zoetmulder, Kalangwan. A Survey of Old Javanese Literature, Den Haag, pp. 126-137. 